University of Nebraska - Lincoln

DigitalCommons@University of Nebraska - Lincoln

Agronomy \& Horticulture -- Faculty Publications

Agronomy and Horticulture Department

10-1969

\title{
Influence of Developmental Stage of Melilotus infesta Leaves on Resistance to Feeding by the Sweetclover Weevil
}

\author{
W. R. Akeson \\ G. L. Beland \\ Francis A. Haskins \\ University of Nebraska-Lincoln, fhaskins@neb.rr.com \\ H. J. Gorz
}

Follow this and additional works at: https://digitalcommons.unl.edu/agronomyfacpub

Part of the Plant Sciences Commons

Akeson, W. R.; Beland, G. L.; Haskins, Francis A.; and Gorz, H. J., "Influence of Developmental Stage of Melilotus infesta Leaves on Resistance to Feeding by the Sweetclover Weevil" (1969). Agronomy \& Horticulture -- Faculty Publications. 290.

https://digitalcommons.unl.edu/agronomyfacpub/290

This Article is brought to you for free and open access by the Agronomy and Horticulture Department at DigitalCommons@University of Nebraska - Lincoln. It has been accepted for inclusion in Agronomy \& Horticulture -Faculty Publications by an authorized administrator of DigitalCommons@University of Nebraska - Lincoln. 


\title{
Influence of Developmental Stage of Melilotus infesta \\ Leaves on Resistance to Feeding by the Sweetclover Weevil ${ }^{1}$
}

\author{
W. R. Akeson, G. L. Beland, F. A. Haskins, and H. J. Gorz ${ }^{2}$
}

\begin{abstract}
Leaves of 6- to 8-week old Melilotus infesta plants contained progressively higher levels of nitrate as the leaves developed from the tightly pinched to the fully expanded stage. In weevil feeding tests on water extracts of these leaves a close relationship was found between actual feeding and the feeding predicted on the basis of nitrate content. At a given level of nitrate, extracts of young $M$. infesta leaves were less attractive to the weevil than were extracts of young $M$. officinalis leaves. Leaves of mature $M$. infesta plants contained very little nitrate, but water extracts of such leaves remained unattractive to the weevil in feeding tests. These extracts were lower in Stimulant $A$ activity and higher in Deterrent $A$ activity than extracts of mature $M$. officinalis leaves. Sweetclover weevil resistance is influenced by the balance between Stimulant $A$, Deterrent $A$, and Deterrent $B$ (nitrate), and the relative contributions of the different factors vary with stage of development of the leaves and the plant. Nitrate appears to be the predominant water-soluble factor in young leaves, and Deterrent $A$ and Stimulant $A$ assume increased importance in leaves from mature plants.
\end{abstract}

Additional index words: Sitona cylindricollis, Nitrate, Feeding stimulant, Feeding deterrent.

$\mathrm{H}^{\mathrm{or}}$ O'T water extracts of young Melilotus infesta Guss. leaves contain three factors which influence feeding by the sweetclover weevil (Sitona cylindricollis (Fahraeus) (4). These factors have been designated Stimulant $A$ and Deterrents $A$ and $B$. Young leaves of weevil-resistant $M$. infesta and a weevil-susceptible species, $M$. officinalis (L.) Lam., appear similar with respect to form and level of Stimulant $\mathrm{A}$ and Deterrent $\mathrm{A}$, but Deterrent $\mathrm{B}$ is much more abundant in the resistant species. Crystalline ammonium nitrate was isolated as the active principle in a fraction of $M$. infesta leaf extract having Deterrent $\mathrm{B}$ activity (3). The authors postulated that nitrate ion was responsible for Deterrent B activity in intact $M$. infesta leaves and in crude water extracts of such leaves, and that the ammonium salt was formed during chromatography with an ammoniacal solvent at an early stage in the purification procedure.

In further studies, water extracts of young $M$. infesta and $M$. officinalis leaves were assayed for nitrate con-

\footnotetext{
${ }^{1}$ A cooperative investigation between the Nebraska Agxicultural Experiment Station, University of Nebraska, and the Entomology Research Division and Crops Research Division, Agricultural Research Service, USDA. Supported in part by ARS Grant No. 12-14-100-8027 (33). Portions of the data are taken from a thesis submitted by G. L. Beland to the Graduate College, University of Nebraska, in partial fulfillment of the requirements for the Master of Science degree. Contribution No. 311 , Department of Entomology, University of Nebraska. Published with the approval of the Director as Paper No. 2502, Journal Series, Nebraska Agricultural Experiment Station. Received April 14, 1969.

${ }^{2}$ Assistant Professor of Agronomy; Research Assistant in Entomology; Bert Rodgers Professor of Agronomy; and Research Geneticist, Crops Research Division, ARS, USDA, respectively, University of Nebraska, Lincoln, Nebr. 68503. The technical assistance of Henry J. Stevens, Agr. Res. Tech., Entomology Research Division, ARS, USDA, is gratefully acknowledged.
}

tent, and various mixtures of the two extracts were offered to adult sweetclover weevils in feeding tests (1). The extent of feeding observed was highly correlated $(r=0.987$ ) with the feeding predicted on the basis of nitrate content of the mixtures.

In the experiments to which reference has been made, young, fully expanded leaves were the source of the extracts. The present studies were conducted in order to compare the results of nitrate determinations and weevil feeding on extracts of $M$. infesta leaves at various stages of development. The possible roles of Stimulant $A$ and Deterrent $A$ and nitrate (Deterrent $\mathrm{B}$ ) in determining weevil feeding responses to mature leaf extracts also were considered.

\section{MATERIALS AND METHODS}

$M$. infesta (Nebraska strain $\mathrm{M} 70)^{3}$ and $M$. officinalis var. 'Goldtop' (F.C. 38,923) plants were grown in the greenhouse in $10-\mathrm{cm}$ clay pots filled with soil. Natural light was supplemented with incandescent lamps to -provide a $16-\mathrm{hr}$ photoperiod. Samples of $M$. infesta leaves at various stages of development (see Table 1) were taken from plants 6,7 , and 8 weeks after planting. Ten plants were selected at random for each weekly sampling. Leaves were detached from the plants and grouped according to stage of development. Samples of the youngest fully expanded leaves of $\boldsymbol{M}$. officinalis were taken from plants similar in age to the $M$. infesta plants.

For samples of leaves from mature plants, 20 plants of each species were used. The youngest fully expanded leaf and the next nine successively older leaves from the same stem were removed from each of the 20 plants. Thus, a 200-leaf sample was obtained for each species. At the time of sampling the $M$. infesta plants were 15 weeks old; all were flowering and seeds were developing on about half of the plants. The $M$. officinalis plants were flowering, but no developing seeds were visible. All leaf samples were weighed, washed with water, dropped into boiling water $(5 \mathrm{ml} / \mathrm{g}$ fresh tissue), and autoclaved for $20 \mathrm{~min}$ at $120 \mathrm{C}$. Autoclaved extracts were cooled, tissue residue was removed, and the extracts were stored in the frozen condition until used.

Stimulant $A$ and Deterrent $A$ fractions were obtained from the mature leaf extracts by ascending preparative chromatography employing Whatman No. $3 \mathrm{MM}^{4}$ filter paper $(2,4)$. Extracts were first chromatographed with a solvent consisting of isopropyl alcohol, concentrated ammonium hydroxide, and water $(8: 1: 2, \mathrm{v} / \mathrm{v} / \mathrm{v}$; Solvent I). Bands corresponding in $\mathrm{Rf}$ to Stimulant A and Deterrent A (4) were cut out and eluted with water. The eluates were applied to separate chromatograms which were developed with isopropyl alcohol, acetic acid, and water $(8: 1: 3, \mathrm{v} / \mathrm{v} / \mathrm{v}$; Solvent II). Again the appropriate bands were cut out and eluted with water to yield partially purified fractions.

The possible presence of previously undetected feeding deterrents in extracts of mature $M$. infesta leaves was investigated chromatographically. After development with Solvent I, chromatograms were cut into six horizontal bands of approximately equal size, and eluates of these bands were assayed for deterrent activity. Eluates in which activity was detected were chromatographed with Solvent II. Bands from the resulting chromatograms were eluted, and the eluates were assayed.

The sweetclover root disk bioassay $(4,5)$ was used in detecting feeding stimulants and deterrents. This test involved the treat-

${ }^{3}$ This strain of $M$. infesta originated in Algeria and is the seed increase from a sample obtained from George Stevenson and Hugo Gross, Canada Dept. of Agriculture, Brandon, Manitoba, Canada as Brandon No. 61-98.

* Mention of a proprietary product does not necessarily imply its endorsement by the USDA. 
ment of sweetclover root disks with the solutions to be assayed, and the presentation of these treated disks to adult sweetclover weevils (two weevils per disk) for feeding. The extent to which the disks were consumed provided a measure of the feeding response of the weevil to the test solutions.

Nitrate was assayed by the procedure of Woolley, Hicks, and Hageman (6) as modified by Akeson, Beland, and Manglitz (1).

Dry weight determinations were based on representative leaf. samples dried at $110 \mathrm{C}$ for 6 hours.

\section{RESULTS AND DISCUSSION}

Progressive increases in the dry weight of developing $M$. infesta leaves were accompanied by increases in nitrate concentration (Table l). This pattern was consistent for plants 6,7 , and 8 weeks old, although the nitrate content of leaves at comparable stages of development varied somewhat from week to week. Nitrate content of the youngest fully expanded leaf of $M$. officinalis ranged from about $5 \%$ of the level observed in similar $M$. infesta leaves, in plants 6 weeks of age, to about $17 \%$ in plants 8 weeks old. At all three of the sampling times, the nitrate level in very young leaves of $M$. infesta was below the level in fully expanded $M$. officinalis leaves.

The predicted feeding values shown in Table 1 were read from a graph in which feeding response $(\%$ of disk area consumed) was plotted against nitrate level $(1,3)$. Data for the graph came from a feeding test in which bioassay disks were treated with a constant level of Stimulant A and varying levels of ammonium nitrate. The close correlation ( $r$ values ranging from 0.90 to 0.99 , Table 1) between predicted and actual feeding indicates that in these comparisons, as in other studies (1), nitrate level exerted a strong influence on feeding response. However, close examination of the data suggests that at a given level of nitrate, extracts of $M$. officinalis leaves were more conducive to weevil feeding than were extracts of $M$. infesta leaves. In addition, for the $M$. officinalis leaf extracts, actual feeding was consistently greater than that predicted on the basis of nitrate level, while for $M$. infesta actual feeding was considerably lower than

Table 1. Effect of stage of leaf development on nitrate level and resistance to weevil feeding.

\begin{tabular}{|c|c|c|c|c|c|c|}
\hline \multirow[b]{2}{*}{$\begin{array}{l}\text { Age of } \\
\text { plants, } \\
\text { weeks }\end{array}$} & \multirow[b]{2}{*}{ Spectes } & \multicolumn{2}{|c|}{ Deseription of leaf sample } & \multirow[b]{2}{*}{$\begin{array}{c}\text { Nitrate } \\
\text { N, } \\
\text { ppm } \\
\text { dry wt }\end{array}$} & \multicolumn{2}{|c|}{ Extent of feeding* } \\
\hline & & $\begin{array}{c}\begin{array}{c}\text { Stage of } \\
\text { development }\end{array} \\
\end{array}$ & $\begin{array}{c}\text { Dry wt, } \\
\text { mg/' } \\
\text { leaflet }\end{array}$ & & $\begin{array}{c}\text { Predic- } \\
\text { ted } \dagger \\
(\%)\end{array}$ & $\begin{array}{l}\text { Actualf }(S) \\
\text { mean } \pm S E\end{array}$ \\
\hline \multirow[t]{2}{*}{6} & M. infesta & $\begin{array}{l}\text { Pinched } \\
\text { Unfolding } \\
\text { Unfolded } \\
\text { Fully expanded }\end{array}$ & $\begin{array}{l}0.8 \\
2.8 \\
5.6 \\
7.4\end{array}$ & $\begin{array}{r}270 \\
2,500 \\
5,240 \\
8,010\end{array}$ & $\begin{array}{r}52.0 \\
15.0 \\
6.0 \\
2.7\end{array}$ & $\begin{array}{r}52.3 \pm 2.8 \\
7.1 \pm 1.2 \\
0.7 \pm 0.3 \\
0.0 \pm 0.0\end{array}$ \\
\hline & M. officinabs & Fully expanded & 4.1 & 430 & \multicolumn{2}{|c|}{$\mathrm{r}=0.99 * *$} \\
\hline \multirow[t]{3}{*}{7} & M. infesta & $\begin{array}{l}\text { Tightly pinched } \\
\text { Loosely pinched } \\
\text { Unfolding } \\
\text { Unfolded } \\
\text { Fully expanded }\end{array}$ & $\begin{array}{l}0.5 \\
1.2 \\
3.6 \\
6.4 \\
7.9\end{array}$ & $\begin{array}{r}180 \\
340 \\
750 \\
2,280 \\
4,110\end{array}$ & $\begin{array}{r}53.0 \\
51.0 \\
43.0 \\
16.5 \\
8.0\end{array}$ & $\begin{array}{r}56.2 \pm 2.7 \\
51.2 \pm 3.1 \\
23.4 \pm 3.2 \\
12.6 \pm 2.8 \\
4.0 \pm 1.2\end{array}$ \\
\hline & M, officinalis & Fully expanded & 3.7 & 230 & 52.0 & $70.8 \pm 1.9$ \\
\hline & & & & & \multicolumn{2}{|c|}{$r=0.90^{* *}$} \\
\hline \multirow[t]{3}{*}{8} & M. infesta & $\begin{array}{l}\text { Tightly pinched } \\
\text { Loosely pinched } \\
\text { Unfolding } \\
\text { Unfolded } \\
\text { Fully expanded - I } \\
\text { Fully expanded - } 2\end{array}$ & $\begin{array}{l}0.5 \\
1.2 \\
3.4 \\
6.0 \\
8.4 \\
8.4\end{array}$ & $\begin{array}{r}70 \\
140 \\
1,110 \\
3,120 \\
4,760 \\
5,960\end{array}$ & $\begin{array}{r}56.0 \\
56.0 \\
36.0 \\
13.0 \\
6.5 \\
5.0\end{array}$ & $\begin{array}{r}63.1 \pm 2.8 \\
41.6 \pm 3.7 \\
29.8 \pm 2.8 \\
7.2 \pm 1.0 \\
2.4 \pm 0.8 \\
0.6 \pm 0.2\end{array}$ \\
\hline & M. officinalis & Fully expanded & 4.3 & 790 & 42.0 & $53.1 \pm 3.9$ \\
\hline & & & & & \multicolumn{2}{|c|}{$r=0.94^{* *}$} \\
\hline
\end{tabular}

* Feeding values are expressed as percentar: of disk area consumed, $\dagger$ Feeding predicted from nitrate content. $\ddagger$ Each treatment $(5$ root disks treated with extract representing $4.5 \mathrm{mg}$ dry leaf tissue) was replicated five times, ** Coefficients of correlation between predicted and actual feeding are signiticant at the 0.01 level of probability. predicted except in the case of leaves in the early stages of development.

Prediction of feeding response on the basis of nitrate content involves the tacit assumption that the extracts tested are equivalent to each other, and to the solutions used in establishing the feeding response graph, with respect to all feeding factors except nitrate. The observations just cited indicate that this assumption is not completely valid for young leaves of $M$. infesta and $M$. officinalis. The assumption is certainly invalid with reference to leaves from mature M. infesta plants. Beland (G. L. Beland, 1968. Effect of nitrate distribution in Melilotus infesta Guss. on resistance to the sweetclover weevil. M.S. Thesis. University of Nebraska, Lincoln) reported a pronounced drop in nitrate content of $M$. infesta leaves at about the time of flowering (approximately ten weeks after planting), and a gradual decline thereafter. However, extracts of these low-nitrate leaves, like extracts of leaves from mature $M$. infesta plants in the present study (Table 2, A), were not attractive to the weevil in feeding tests.

Inasmuch as the lack of feeding on leaves from mature $M$. infesta plants cannot be ascribed to a high content of nitrate, the possible influence of Stimulant $A$ and/or Deterrent $A$ in mature leaf extracts was investigated. Nitrate assays of these extracts indicated nitrate contents of less than $200 \mathrm{ppm}$ in the mature leaves of both species. In a comparison of the two crude extracts, extensive feeding occurred on disks treated with the $M$. officinalis extract, and almost none was observed on $M$. infesta extract-treated disks (Table 2, A). The Stimulant A fraction from $M$. infesta promoted much less feeding than the comparable fraction from $M$. officinalis (Table 2, B). On the other hand, the Deterrent A fraction from $M$. infesta displayed much more feeding deterrent activity than the Deterrent $\mathrm{A}$ fraction from $M$. officinalis (Table 2, C). Combination of the respective Stimulant $A$ and Deterrent $\mathrm{A}$ fractions for the two species produced mix. tures with feeding properties very similar to the original extracts (Table 2, compare D and A). This similarity suggests that Stimulant $A$ and Deterrent $A$ were primarily responsible for the feeding response elicited by the mature leaf extracts.

Table 2. Feeding by sweetclover weevils on root disks treated with crude hot water extracts or chromatographically purified Stimulant $A$ and Deterrent $A$ fractions from leaves of mature Melilotus plants.

\begin{tabular}{|c|c|c|c|c|c|c|}
\hline \multirow[b]{2}{*}{ Comparison } & \multicolumn{5}{|c|}{ Solution used in bloassay (ml) } & \multirow{2}{*}{$\begin{array}{c}\text { Disk area } \\
\text { consumed } \\
\text { mean } \pm \mathrm{SE} \\
(\%)\end{array}$} \\
\hline & Water & $\begin{array}{l}\text { Crude } \\
\text { extract }\end{array}$ & $\begin{array}{c}\text { Blank } \\
\text { fraction* }\end{array}$ & $\begin{array}{c}\text { Stimulant } \\
\text { At }\end{array}$ & $\begin{array}{c}\text { Deterrent } \\
\text { A }\end{array}$ & \\
\hline $\begin{array}{l}\text { A. Crude extract } \\
\text { Controi } \\
\text { M. infesta } \\
\text { M. . officinalis }\end{array}$ & $\begin{array}{l}\text { assay } \\
0.15 \\
0.10 \\
0.10\end{array}$ & $\begin{array}{l}0.05 \\
0.05\end{array}$ & & & & $\begin{array}{r}2.6 \pm 1.3 \\
2.7 \pm 0.7 \\
50.6 \pm 5.6\end{array}$ \\
\hline $\begin{array}{l}\text { B. Assay of Stim } \\
\text { Control } \\
\text { M infesta } \\
\text { M. Officinalis }\end{array}$ & $\begin{array}{l}\text { nulant } \mathrm{A} \\
0.10 \\
0.10 \\
0.10\end{array}$ & action & 0.05 & $\begin{array}{l}0.05 \\
0.05\end{array}$ & & $\begin{array}{r}0.7 \pm 0.2 \\
5.8 \pm 1.1 \\
48.5 \pm 4.6\end{array}$ \\
\hline $\begin{array}{l}\text { C. Assay of Dete } \\
\text { Control } \\
\mathrm{M} . \text { infesta } \\
\underline{\mathrm{M}} \text { officinalis }\end{array}$ & $\begin{array}{c}\text { errent A } \\
0.05 \\
0.05 \\
0.05\end{array}$ & action & 0.05 & $\begin{array}{l}0.05 \\
0.05 \\
0.05\end{array}$ & $\begin{array}{l}0.05 \\
0.05\end{array}$ & $\begin{array}{r}52.6 \pm 4.6 \\
8.9 \pm 1.5 \\
31.3 \pm 4.4\end{array}$ \\
\hline $\begin{array}{l}\text { D. Assay of com } \\
\text { Control } \\
\text { M. infesta } \\
\text { M. officinalis }\end{array}$ & $\begin{array}{l}\text { abined fr } \\
0.05 \\
0.05 \\
0.05\end{array}$ & ti.ons & 0.10 & $\begin{array}{l}0.05 \\
0.05\end{array}$ & $\begin{array}{l}0.05 \\
0.05\end{array}$ & $\begin{array}{r}2.2 \pm 0.7 \\
4.0 \pm 0.8 \\
52.7 \pm 6.5\end{array}$ \\
\hline
\end{tabular}


Table 3. Assay of chromatographic fractions of a hot water extract of leaves from mature $M$. infesta plants for deterrent activity.

\begin{tabular}{lccc}
\hline Band & $\mathrm{R}_{\mathrm{f}}$ & $\begin{array}{c}\text { Corresponding } \\
\text { active fraction }\end{array}$ & $\begin{array}{c}\text { Disk area consumed* } \\
\text { mean } \pm \mathrm{SE}(\%)\end{array}$ \\
\hline 1 & $0.00-0.17$ & Deterrent $\mathrm{A}$ & $7.6 \pm 3.1$ \\
2 & $0.17-0.33$ & & $27.3 \pm 11.1$ \\
3 & $0.33-0.47$ & Stimulant A & $52.0 \pm 6.6$ \\
4 & $0.47-0.67$ & Deterrent B & $66.7 \pm 3.0$ \\
5 & $0.67-0.83$ & & $58.1 \pm 5.5$ \\
6 & $0.83-1.00$ & & $52.3 \pm \mathbf{6 . 9}$ \\
\hline * Each treatment consisted of 5 root disks treated with Stimulant A from $\mathrm{M}$. officinalis \\
(representing 4.5 mg dry tissue) mixed with the indicated chromatographic fraction \\
from an equal amount of $\underline{\mathrm{M}}$ infesta tissue.
\end{tabular}

To test the possibility that the feeding deterrent activity of the extract of mature $M$. infesta leaves might involve substances not previously detected, leaf extracts were chromatographed with Solvent I, and eluates of the developed chromatogram were assayed (Table 3). Eluates of band 1, and possibly band 2, displayed feeding deterrent activity; eluates of the other four bands had little influence on feeding. Rechromatography of the active eluates with Solvent II produced chromatograms in which the deterrent activity was confined to a band between Rf 0.17 and 0.30 . This location corresponds to the location of Deterrent $A$ in this particular solvent. Thus, Deterrent A was the only feeding deterrent detected in mature leaves of $M$. infesta.

The results of these studies support the hypothesis that sweetclover weevil resistance is influenced by the balance between Stimulant A, Deterrent A, and Deterrent $B$ (nitrate). The relative contributions of the different factors vary considerably with stage of de- velopment of the leaves and the plant. Nitrate appears to be the predominant water-soluble factor in young leaves, and Deterrent $A$ and Stimulant $A$ assume increased importance in leaves from mature plants. Recent evidence obtained in this laboratory indicates that certain sugars are responsible for Stimulant A activity. The identity of Deterrent $A$ is not known. A more complete understanding of the mechanism of resistance and susceptibility must await the identification of Deterrent $A$ as well as active factors which may be present in the lipid fraction of $M$. infesta extracts.

\section{LITERATURE CITED}

1. Akeson, W. R., G. L. Beland, and G. R. Manglitz. 1969. Nitrate as a deterrent to feeding by the sweetclover weevil. $\mathrm{J}$. Econ. Entomol. (In press).

2. Akeson, W. R, H. J. Gorz, F. A. Haskins, and G. R. Manglitz. 1968. A water-soluble factor in Melilotus officinalis leaves which stimulates feeding by the adult sweetclover weevil. J. Econ. Entomol. 61:1111-1112.

3. Akeson, W. R., F. A. Haskins, and H. J. Gorz. 1969. Sweetclover-weevil feeding Deterrent B: Isolation and identification. Science 163:293-294.

4. Akeson, W. R., F. A. Haskins, H. J. Gorz, and G. R. Manglitz. 1968. Water-soluble factors in Melilotus leaves which influence feeding by the sweetclover weevil. Crop Sci. 8:574-576.

5. Akeson, W. R., G. R. Manglitz, H. J. Gorz, and F. A. Haskins. 1967. A bioassay for detecting compounds which stimulate or deter feeding by the sweetclover weevil. J. Econ. Entomol. 60:1082-1084.

6. Woolley, J. T., G. P. Hicks, and R. H. Hageman. 1960. Rapid determination of nitrate and nitrite in plant material. Agr. and Food Chem. $8(6): 481-482$. 